This is an Accepted Manuscript of an article published by Taylor \& Francis in Journal of Policy Research in Tourism, Leisure and Events on 3 July 2017, available online: http://www.tandfonline.com/doi/full/10.1080/19407963.2017.1344245

\title{
The widening gap between Malaysia's international tourism brand and domestic multicultural policy
}

Nathan John Albury, University of Oslo \& Li Hsien Ooi, Wawasan Open University

\begin{abstract}
Malaysia's international image boasts harmonious multiculturalism amongst Malay, Chinese, Indian and Indigenous ethnolinguistic groups, alluring tourists and investors worldwide. Campaigns such as Malaysia, Truly Asia promise a rich and diverse cultural experience, and the government's international investment arm describes Malaysians as Western-leaning. On the other hand, Malaysian laws, policies and subsequent scholarship show that Malaysian society is hierarchised by ethnicity and language. Through a lens of critical multiculturalism, this paper reflects on a mismatch between Malaysia's international image and domestic policy. We argue that Malaysia's international image has likely never been accurate and instead caters towards Western values. Rather than all ethnicities being equal, Malaysia is an ethnocratic state that has codified the supremacy of being Malay. We suggest that the gap between this international image and domestic multicultural experience may only be widening with a resurgence of Islamisation in Malaysian politics and society.
\end{abstract}

\section{Keywords}

Malaysia; Malaysia Truly Asia; tourism branding; multiculturalism 


\section{This is an Accepted Manuscript of an article published by Taylor \& Francis in Journal of Policy Research in Tourism, Leisure and Events on 3 July 2017, available \\ online: http://www.tandfonline.com/doi/full/10.1080/19407963.2017.1344245}

\section{Introduction}

Malaysia remains an attractive and popular tourist destination, which is in no small part attributable to a favourable exchange rate for international visitors, political stability, its tropical environment, culinary opportunities and especially its cultural and linguistic diversity (Nanthakumar, Subramaniam, \& Kogid 2012). Accordingly, those unfamiliar with international politics can be forgiven for perceiving Malaysia as a multicultural utopia where ethnicities, religions, and languages from across Asia not only co-exist harmoniously, but thrive. This is by no means coincidental, but attributable to the success of Malaysia's international marketing campaigns. The Malaysia, Truly Asia tourism campaign since 1999 proposes an alluring image whereby the Muslim Malay majority embraces and celebrates the cultural and linguistic diversity offered by the Chinese and Indian minority groups. This aims to give the foreign visitor a rich multicultural experience that the government prides itself on. The branding has been successful, so successful that it has been decorated with a string of international marketing awards (Tourism Malaysia 2014). As the campaigners themselves have boasted, "nowhere is there such exciting diversity of cultures, festivals, traditions and customs, offering myriad experiences. No other country is "Truly Asia" as Malaysia” (Tourism Malaysia 2015). The Malaysian Investment Development Authority (Malaysian Investment Development Authority 2015) offers a similar image to attract foreign investment in the country. Beyond describing the stability of the Malaysian political environment and the country's well-developed business and technology infrastructure, the authority commodifies Malaysia's ethnolinguistic diversity and eagerly advertises its young, multicultural, and multilingual 


\section{This is an Accepted Manuscript of an article published by Taylor \& Francis in Journal of Policy Research in Tourism, Leisure and Events on 3 July 2017, available online: http://www.tandfonline.com/doi/full/10.1080/19407963.2017.1344245}

workforce to potential investors (Malaysian Investment Development Authority 2015). At the historic cross roads of civilisations, religions, and languages in Southeast Asia, Malaysia appears to shine as a success story of multiculturalism and multilingualism.

With that marketed image picture in mind, this paper takes a critical perspective of the international image of harmonious multiculturalism that Malaysia has created for itself by bringing that image face-to-face with Malaysia's domestic social polciies as they concern cultural and ethnic diversity. It then turns to critically investigate and analyse domestic politics of multiculturalism and multilingualism to reveal what appears to be an expanding fracture between Malaysia's international image and its domestic experiences. Drawing on critical multiculturalism, with its interdisciplinary interest in "structural analysis of unequal power relationships" (May \& Sleeter 2010:10) the paper shows that successive Malay-dominant governments have sought to regulate diversity in the interests of nation-building through an ethnocratic policy that favours the Malays. This, it is argued, is inconsistent with Malaysia's international image that exploits a western idea of multiculturalism and the ethnic and cultural egalitarianism it presupposes. The paper then argues that a renewed process of Islamisation in domestic politics amounts to moral monism (Parekh 2002) whereby Malay culture, religion and language are increasingly constructed as superior above those of Chinese, Indian and Indigenous Malaysians. This leads to the conclusion that the international image is especially an activity in political branding (Pasotti 2010) and that Malaysia may be diverting even further away from the multicultural and multilingual brand that Malaysia's international marketers have created and brought to television screens and newspapers worldwide. In order to do this, the paper firstly sketches out Malaysia's ethnic, cultural and linguistic diversity 


\section{This is an Accepted Manuscript of an article published by Taylor \& Francis in Journal of Policy Research in Tourism, Leisure and Events on 3 July 2017, available online: http://www.tandfonline.com/doi/full/10.1080/19407963.2017.1344245}

and then examines Malaysia's international image, taking lead from the tourism and international investment pages offered by the government's public interface at Malaysia.gov.my.

\section{A multicultural and multilingual Malaysia}

Malaysia gained independence from the British in 1957 as a culturally, ethnically and linguistically diverse union of nations. As a result of waves of migration throughout history from today's southern China and India, the Malaysian peninsula has long been shared with non-Malays. This diversity only increased when Sarawak and Sabah joined the Malaysian federation in 1963 some years after Malaysian independence, as the national population then came to also comprise indigenous communities, cultures and languages from the island of Borneo. Today, the Bumiputera (sons of the soil, which refers to the Malay and Indigenous Malaysians) constitute about $67 \%$ of the Malaysian population, the Chinese around 25\%, and the Indians around $7 \%$.

This ethnic pluralism is reflected in religious and linguistic diversity. Whereas the Malays are almost exclusively Muslim, the Indians have brought Hinduism to Malaysia, the Chinese have brought Buddhism and Taoism, and the largest single religious group in Sarawak is Christian. As the Indians had mostly migrated from the Madras Presidency, the community's predominant language is Tamil, however smaller migrations from other areas of India have brought the Punjabi, Malayalam and Telugu languages. The Chinese mostly originated from southern China, and brought with them several mutually unintelligible Chinese varieties, including Hokkien, Hakka, Cantonese, Teochew, Foochow, and Hainanese among others. However, the Chinese have been inspired by Beijing politics and have instituted Mandarin as their pan-Chinese community lingua 


\section{This is an Accepted Manuscript of an article published by Taylor \& Francis in Journal of Policy Research in Tourism, Leisure and Events on 3 July 2017, available online: http://www.tandfonline.com/doi/full/10.1080/19407963.2017.1344245}

franca (Gill 2013). The predominant language amongst the Malay has remained Bahasa Melayu. Today, ethnicity and religion continue to be primary social markers and the main resource with which Malaysians self-identify (Gill 2005; Noor \& Leong 2013).

\section{The international image}

This diversity, parallel to Malaysia's recent and rapid economic development, has made for an appealing image sponsored by the Malaysian state for international tourism, and to a lesser degree international investment. The Malaysia.gov.my website is a public portal for official details about tourism and investment opportunities in Malaysia, from which the international image has been analysed for the purposes of this paper. The Malaysian Investment Development Authority (2015) refers to the country's political stability and rapid economic development to woo foreign investors, and describes the Malaysian workforce is marketed as young, vibrant, friendly, mobile, English speaking, and profiting from peaceful industrial relations. This image seems to have been appropriated by the private sector. For example, in its guide to those seeking to conduct business in Malaysia, Pricewaterhouse Coopers (2014) explains that Malaysia's government departments use English, that Indigenous Malay business is thriving, and that non-Malay medium schooling is welcome and abundant. Malaysia's Property Investment (2016) site similarly explains that "the society of Malaysia is multicultural. It has a mix of three races namely Malay, Chinese and Indian, living in exemplary harmony". The picture of Malaysia is one of a Western-leaning, English speaking, eagerly and successfully multicultural and multilingual nation. 


\section{This is an Accepted Manuscript of an article published by Taylor \& Francis in Journal of Policy Research in Tourism, Leisure and Events on 3 July 2017, available \\ online: http://www.tandfonline.com/doi/full/10.1080/19407963.2017.1344245}

However, the intersection of Malay, Indian and Chinese cultures, languages, and religions against a backdrop of white sandy beaches and exotic local foods, makes Malaysia attractive to foreign tourists. In 2014 Malaysia held its fourth Visit Malaysia Year with the express purpose to "reflect the diversity in unity of all Malaysians" (Tourism Malaysia, 2015a). This seemingly celebrates Malaysia as a harmonious, unified, and potentially egalitarian multiculturalism. Since 1999, Tourism Malaysia has delivered the Malaysia, Truly Asia campaign, claiming "there is only one place where all the colours, flavours, sounds and sights of Asia come together" and that "this place is full of variety and this diversity extends to its cities, languages and landscapes as well” (Tourism Malaysia 2015). This paints an alluring picture of ethnic, cultural and linguistic diversity that makes Malaysia unique. The campaign has been so successful that it has been awarded successive marketing prizes (Tourism Malaysia, 2014).

Morais (2013) has offered a detailed critical analysis of the Malaysia, Truly Asia campaign vis-à-vis its representation of packaged ethnicities as supposed Malaysian identities. She especially argues that the identities offered by Malaysia, Truly Asia are "more contrived than reflective of what one encounters in homes and offices and on the street" (p. 93) and that, in terms of multicultural representation, it "flaunts inter-racial goodwill and harmony" (p. 98). Morais also shows that many of the campaign's images of ornately and ceremonially dressed women present Malaysia as an Asian cosmopolitan and especially target the male leisure traveller. It presents a silent image of linguistic and cultural diversity, which Kelly-Holmes (2014) might describe as an advertised fetish. Notably, these female hosts, as Morais describes them, may appear in Malay sarongs, Indian sarees and Mandarin gowns, but not in tudung, the traditional head dress of women 


\section{This is an Accepted Manuscript of an article published by Taylor \& Francis in Journal of Policy Research in Tourism, Leisure and Events on 3 July 2017, available online: http://www.tandfonline.com/doi/full/10.1080/19407963.2017.1344245}

from the Malay majority. In as far as marketing theory says that at the core of marketing activity lies "an exchange process where value is given and received" (Day 2000, p. 24), Malaysia, Truly Asia, Morais argues, reduces Malaysia to what "the Western world thinks, wants and expects" (p. 104) rather than reflecting a shared Malaysian identity. In postcolonial Malaysia that is linguistically, culturally and religiously diverse, what this collective interethnic national identity might be, if one exists, is entirely unclear.

\section{A critical review of multicultural policy}

With this in mind, we now position this international image of harmonious multiculturalism vis-àvis domestic social policy to highlight a mismatch between the two. To do this, we draw from existing literature and primary government sources and critically reflect on how the Malaysian state has responded to domestic diversity. Before moving on to argue that a renewed Islamisation of Malaysian politics and society renders Malaysia's international image as even less realistic, this section shows that the authenticity of the image has long been at least dubious.

Upon securing independence in 1957 subsequent to the rise of Malay nationalism, a core policy task was to define and build the Malaysian nation in economic, social and linguistic terms. Islam was regarded by Malays as an ideal foundation to the modern nation-state, as it is a religion of peace and tolerance that strives for inclusiveness (Benthall 2005). Accordingly, the country's founding fathers envisioned Malaysia a harmoniously multicultural society under a government with Islamic principles. A new cohesive identity would be formed by way of Bahasa Melayu - later renamed to Bahasa Malaysia to connote interethnic inclusiveness - as the single official language of 


\section{This is an Accepted Manuscript of an article published by Taylor \& Francis in Journal of Policy Research in Tourism, Leisure and Events on 3 July 2017, available online: http://www.tandfonline.com/doi/full/10.1080/19407963.2017.1344245}

the state (Government of Malaysia, 1957). However, as Albury and Aye (2016) explain, language and ethnicity are synonymous in Malaysia and the move to Bahasa Malaysia especially reflected Malay nationalist intentions. The state sought to see the "ascendancy of Malay politics, language and culture" (Pennycook 1994:195) above those of the Chinese and the Indian minority groups. As Bumiputera, the Malays came to consider themselves as deserving preferential rights and treatment vis-à-vis the Chinese and the Indians who continue to be discursively constructed as visitors, known as Pendatang, to Malaysia (Frith 2000). Accordingly, the Malaysian constitution was drafted to reflect this special position of the Bumiputera above the other races, rather than foster political equality with Pendatang. Not only is Bahasa Malaysia the national language, but questioning its legislated supremacy amounts to sedition, as the hegemonic policy -intimately intertwined in Malaysia with race relations - is seen as inciting racial discord.

Like Bahasa Malaysia, Islam too was codified as defining modern Malaysia. The constitution stipulates that Islam is the religion of the federation, but this is parallel to provisions for freedom of religion at Article 11. This reflects a turbulent policy-making process whereby secularism and the role of Islam in the Constitution and in nation-building were subject to debate and negotiation between Malaysian political leaders, Islamic leaders, and British legal counsellors (Martinez 2001, 2004). The constitution even defines being Malay as being Muslim, meaning that any Malay person who renounces Islam loses the privileges associated to being Malay as set out in the constitution. The religions of the other ethnic groups receive no mention. Ultimately, nonMalay languages and cultures have been purposefully excluded from legislative definitions of 


\section{This is an Accepted Manuscript of an article published by Taylor \& Francis in Journal of Policy Research in Tourism, Leisure and Events on 3 July 2017, available online: http://www.tandfonline.com/doi/full/10.1080/19407963.2017.1344245}

modern Malaysia, and their languages and cultural practices are to be tolerated only in unofficial domains.

The resulting ethnic tensions led to race riots in 1969. The Malay feared that their relatively lower socioeconomic standing would diminish Malay political control, and non-Malay feared they would be assimilated into a Malay identity (Noor \& Leong 2013). The resulting political response was to manage ethnic tensions by "expanding the interests of Malays as a dominant ethnic group rather mediating the interests of all ethnic communities" (Haque 2003:245). This was pursued by way of the 1971 New Economic Policy (NEP) which would give affirmative action to Malays - and Bumiputera more generally - by way of quotas for preferential access to housing, employment, education and share-ownership. As an economic policy it successfully established a Malay middle class (Fenton 2003). From a sociological perspective, however, the NEP consolidated essentialised but hierarchised ethnic categorisation as the defining structure of Malaysian society. In itself, this essentialisation appears not to have been with rejected by Malaysians (Joseph 2003:171). This would likely explain the stunted successes of Bangsa Malaysia, a policy programme from the 1990s that promoted a fabricated Malaysian race and promoted self-identification not on ethnic lines but as Malaysians (Ridge 2004).

However, opposition surfaced, especially in the Chinese and Indian communities, on the basis that affirmative action for the Malay disregarded those non-Malays who have welfare needs, and on the basis of inequality in accessing socioeconomic opportunities. Prime Minister Najib Razak's 1Malaysia policy would seek to rectify these inequalities to some degree by promoting multiculturalism, offering assistance on the basis of need, and instituting parity between the races in 


\section{This is an Accepted Manuscript of an article published by Taylor \& Francis in Journal of Policy Research in Tourism, Leisure and Events on 3 July 2017, available online: http://www.tandfonline.com/doi/full/10.1080/19407963.2017.1344245}

practical policy terms through meritocracy. In real terms, however, the impact has been minimal. For example, the Malays still enjoy special quotas to employment, and any Malaysian who seeks entrance to a public university must pass a Bahasa Malaysia exam.

Despite this Malay-led diversity, multiculturalism has been popular as a term amongst Malaysian themselves when depicting their diversity (Guan 2011) and this has also been used to describe Malaysian society in academic terms borrowed from the West. For example, Noor and Leong (2013) have discussed Malaysia in comparative context with Singapore as a model of multiculturalism, explaining that Malaysian multiculturalism focusses on reducing tensions and avoiding community violence. Gill (2013) refers to Malaysia as multicultural to discuss national language policy, and Hamayotsu (2014) suggests that Malaysia seeks to achieve multiculturalism but is yet to do so as it remains divided upon ethnic lines. Ibrahim (2007) discusses multiculturalism as an active and current process of negotiation, and identifies Malaysia as multicultural in a similar way to the United States, New Zealand, and Nigeria on the basis of heterogeneity.

However, the term multiculturalism in itself is not epistemologically benign, and Malaysia's Malay-dominant politics conceptualise cultural, ethnic, and linguistic diversity specifically in Malay, non-Western, sociohistorical terms. Whereas western notions of multiculturalism lean towards concepts of democracy, equality, equity and social justice (Yow 2016), the Malay political agenda sooner perceives its diversity as cultural pluralism (Fenton 2003) whereby different ethnicities and cultures co-exist but these differences need not be reconciled. Instead, Malaysian pluralism allows for ethnocratic supremacy and stratification. For example, the 


\section{This is an Accepted Manuscript of an article published by Taylor \& Francis in Journal of Policy Research in Tourism, Leisure and Events on 3 July 2017, available online: http://www.tandfonline.com/doi/full/10.1080/19407963.2017.1344245}

American notion of the melting pot - whether this refers to assimilation or its updated connotation of integration - contrasts with the Malaysian perception of multiculturalism. Ethnolinguistic belonging in Malaysia is so strong that the country's ethnic groups are by no means on a path to assimilation into becoming, for example, Malay. By the same token, the imposition of essentialised ethnic and religious categories by both the Malaysian government and Malaysian society more broadly means integration into becoming Malaysian, in a sense void of ethnic essentialisation, also seems unlikely. Instead, different ethnicities connote different religions, linguistic allegiances, socioeconomic standing, and even attract different legal rights. Ethnic categorisation is so salient that ethnicities are even named on Malaysian identity cards. In this regard, the images of Malaysia, Truly Asia and of the investment marketers may be accurate in that different ethnolinguistic groups do indeed co-exist in Malaysia and advance identifiably distinct cultural identities. The images do not, however, depict the cultural, linguistic and religious supremacy afforded to the Malay majority in Malaysian law. Instead these images - and knowing they target the West - seem to sooner reflect a western understanding of multiculturalism that appeal to western tourists with presuppositions of harmony and egalitarianism than the pluralist, ethnically stratified and ethnocratic state policy that upholds the divine supremacy of being Malay.

\section{Islamisation}

Reflecting on recent Malaysian events and discourses, and bringing together different scholarship on Malaysian society, the paper now shows that the multicultural utopia presented in Malaysia's international tourism image is perhaps becoming increasingly more distant and unrealistic. This 


\section{This is an Accepted Manuscript of an article published by Taylor \& Francis in Journal of Policy Research in Tourism, Leisure and Events on 3 July 2017, available \\ online: http://www.tandfonline.com/doi/full/10.1080/19407963.2017.1344245}

comes as a result of a resurging, moral monist Islamisation underway in Malaysian politics and society. Moral monism "refers to the view that only one way of life is fully human, true, or the best, and that all others are defective to the extent that they fall short of it" (Parekh 2002:16). Parekh (2002) explains that monists recognise rather ignore cultural diversity, but assert a certain good and certain truths about human nature. In the case of Malaysia, we argue that in the post Bangsa Malaysia and 1Malaysia eras, this good and these truths are now commonly based in Islamic philosophy rather than in any ideology of egalitarian multiculturalism, and Islam is increasingly cited as justification for structural inequalities and the supremacy of Malayness that Malaysia's international image disguises. As Frith (2000) explains, "Islam is not only the faith of the Malays: it serves also as one of the core foundations upon which their self-identity is based" (p. 117). Given Islam is the core identity of the Malays, is their ultimate truth, and this truth is codified in the legal system through Syariah law and in the constitution, it is not difficult to see that critical discourses about Malay socioeconomic privileges result in defence of Islam and references to Islam in interethnic politics. This creates a fertile ground for Islamisation whereby the application of Islamic values is expanding into interethnic contexts in the pursuit of interethnic harmony.

Islamisation is immediately apparent if one considers how the status of being Bumiputera in Malaysia is operationalised. Whereas under Malaysian law being Bumiputera includes Malay and non-Malay peoples premised on being Indigenous to Malaysia and therefore deserving of socioeconomic advantages, being a Malay Bumiputera is in effect hierarchised above being a nonMalay Bumiputera. The languages of non-Malay Bumiputera which are not recognised in the federal constitution, are generally not afforded official status, and are generally not taught as a 


\section{This is an Accepted Manuscript of an article published by Taylor \& Francis in Journal of Policy Research in Tourism, Leisure and Events on 3 July 2017, available online: http://www.tandfonline.com/doi/full/10.1080/19407963.2017.1344245}

subject or medium of instruction (UNICEF 2016). Similarly, Christianity - as the predominant religion of non-Malay Bumiputera in Sabah and Sarawak - does not share equal status with Islam in Malaysian law and is not used to define Malaysia as Islam indeed is. Suggestions that non-Malay Bumiputera can be regarded as Malay on the basis of a shared language have even been rejected on the basis they are not Muslim (Barr \& Govindasamy 2010). As such, a hierarchy exists between Muslim and non-Muslim Bumiputera whereby the Malays, as it stands, seems to be afforded more rights and status in Malaysian law and policy than other Bumiputera.

Secondly, the question of whether Malaysia is in fact a secular state - as the international image might presuppose - or an Islamic state continues to be debated. As Fernando (2006) and Moten (2006) note, the constitution does not clarify that Malaysia is secular nor Islamic. Some have argued that stipulating Islam to be the official religion provides psychological support to the Malays and is largely ceremonial, but Islam nonetheless enjoys "primacy in official public culture" (Fenton 2003:137). For example, leaving Islam or converting to another religion is either illegal or attracts punishment, as sentenced by Syariah courts, including fines, imprisonment, and whipping (Adil 2007), whereas non-Malay conversion to Islam is welcome. This is no doubt premised in the strong conviction that Islam is the ultimate truth, that all people belong to Allah, and those who have not yet converted to Islam are, in effect, lost sheep. The 1980s saw in Malaysia what is called an Islamic resurgence under the auspices of Prime Minister Mahatir Mohammad in the years following the Iranian Revolution. During this time, Islamic banking and the first Islamic university were established (Ghazali 2014). Today, students at non-Malay schools are still provided textbooks that are culturally Malay-oriented and are silent on non-Malay perspectives and traditions. Non- 


\section{This is an Accepted Manuscript of an article published by Taylor \& Francis in Journal of Policy Research in Tourism, Leisure and Events on 3 July 2017, available online: http://www.tandfonline.com/doi/full/10.1080/19407963.2017.1344245}

Malay schools are not required to teach Islamic philosophy per se. Nonetheless, the mandatory history curriculum for all students at government schools includes instruction on Islamic civilisations and the technological advances in Islamic science. Schools are also prohibited from teaching Darwin's theory of natural evolution as this is deemed unIslamic (Joseph 2005). That is to say, the morals and values of Islam permeate policy making.

While Islam has long played an important role in shaping Malaysian society, its influence has been increasing over the last decade including in interethnic domains. As Abbott and Gregorios-Pippas (2010) explain, "from banking to law, from dress to education policy, almost no sector of Malaysian society has escaped the growing influence of Islam upon the socioeconomic and political make-up of the country" (p. 135). This is to say, Malaysia's earlier policies can be perceived as more western-leaning, but this has now given way to a stronger assertion of Islamic principles.

In terms of Malaysian politics, Liow (2003) has explained that as a result of political competition between the ruling United Malays National Organisation (UMNO) and Parti Islam seMalaysia, the Pan Malaysian Islamic Party (PAS) in opposition, the Malaysian government has reinforced the influence and position of Islamic interest groups by increasingly responding to their demands. In particular, political parties have increasingly tussled over who can incorporate Islamic principles most into their governance strategies subsequent to criticisms that that policy platforms from across the political parties had veered away from Quranic principles (Martinez 2001; Mohamad 2010; Saat 2012; Zook 2010). In 2016, the Malaysian government introduced the Malaysian Syariah Index report to measure "the seriousness of government efforts to meet Islamic 


\section{This is an Accepted Manuscript of an article published by Taylor \& Francis in Journal of Policy Research in Tourism, Leisure and Events on 3 July 2017, available \\ online: http://www.tandfonline.com/doi/full/10.1080/19407963.2017.1344245}

standards in its policies and programmes" and in April of that year Prime Minister Najib Razak announced that Malaysia scored $75 \%$ in 2015 , meaning "it is clear that we are on the right track in implementing and fighting for Islamic principles" (Rahim 2016). When the state of Sarawak went to the polls in 2016, PAS declared that only a Muslim should be eligible to lead that state, albeit the largest single religious group in Sarawak is Christian (Ghazali, 2016). While the PAS president claimed that "we accept Chinese and Indians as citizens, we treat everyone equally", he nonetheless argued that "we just want to be advisers to the state government so that they will lead the state fairly and according to the principles of Islam" (ibid).

The country's successive Prime Ministers are well-known to draw on Islamic philosophy and ideals when addressing the heterogeneous Malaysian population. Ghazali's (2014) discourse analysis of Malaysian political speeches by the last three prime ministers, shows a notable shift from secular foundations to Islamisation. The current Prime Minister has even questioned the premises of international human rights framework by exploiting an Islamic lens, explaining that "they call it human rightism, where the core beliefs are based on humanism and secularism as well as liberalism" and then adding that this is "deviationist in that it glorifies the desires of man alone and rejects any value system that encompasses religious norms and etiquettes” (Bystrova 2015).

However, events and discourses perceived as Islamisation are not confined to political circles. In some cases, Islamisation is actually seen as Malaysia's Muslims increasingly looking to emulate life in the original Islamic world, and that what we see today as Islamisation may be better described as Arabisation. Indicators include the increasing use of tudung (headscarves) by Malay women and a move from traditional Malay dressing to perceivably Islamic dressing (Boo 2015). 


\section{This is an Accepted Manuscript of an article published by Taylor \& Francis in Journal of Policy Research in Tourism, Leisure and Events on 3 July 2017, available online: http://www.tandfonline.com/doi/full/10.1080/19407963.2017.1344245}

Interestingly, these do not feature in the alluring images of multiculturalism presented by Malaysia, Truly Asia (Morais 2013). The Sultan of the state of Johor has even urged Malays to "retain their culture instead of trying to imitate the Arabs" (Malay Mail Online 2016b). Islamic sermons are known to speak against ethnic and religious tolerance, and in 2006 a roadshow held by a number of non-government organisations to discuss freedom of religion was received with public anger and shut down by the state (Hoffstaedter 2013). Reports are emerging of Islamic philosophy and prayers being forced into Christian schools (Malay Mail Online 2016a), and police officers are deployed to enforce Islamic law (G25 Malaysia 2016). As Sloane-White (2011) discusses Islamisation, or at least the appropriation of Muslim philosophy, is increasingly emerging as a modus operandi in Malaysian workplaces. She explains that Syariah law has in some businesses “emerged as a novel form of corporate culture, reconfiguring workplace identities and relations in distinctly Islamic ways" (p. 304). Debate has also arisen on abolishing Malaysia's network of vernacular language schools where the government currently provides some support for Mandarin and Tamil-medium instruction at its national-type schools that follow the national curriculum. This has sparked renewed community-level and political debate on the desirability of multilingualism in Malaysia, especially the role of Bahasa Malaysia - which is intrinsically connected to Malay ethnic identity and largely synonymous with Islam - as the means for fostering national unity (FMT Reporters 2016).

These are but a few examples of recent discourses and events interpreted as Islamisation that is affording Malaysia's international image as a multicultural utopia increasingly less currency. Naturally, a question is what conditions have given rise to this resurgence of Islamisation more 


\section{This is an Accepted Manuscript of an article published by Taylor \& Francis in Journal of Policy Research in Tourism, Leisure and Events on 3 July 2017, available online: http://www.tandfonline.com/doi/full/10.1080/19407963.2017.1344245}

broadly in society. The reasons are likely to be multiple. Yow (2016) discusses that Malaysia's minority communities have become more vocal in identifying and expressing their political demands for interethnic egalitarianism . While these demands may not refer to Islam, the Malay response involves religion given the tight interrelation of Malay identity and Islam, as discussed. In this sense, defending Malay privileges naturally invokes the supremacy of Islam as the religion of the majority enshrined as moral monism in the Malaysian constitution. Frith (2000) suggests that some Malay may view Islam as the ultimate solution to easing ethnic tensions and creating a unified Malaysia. The argument is that if all Malaysians were Muslim, then everyone could be considered Bumiputera and equal. Hamayotsu (2014) adds that tensions between the Malay majority and the ethnic minorities tests Muslim loyalty. She explains that moderate and progressive Muslims are pressured to take more conservative Islamic positions so that the boundaries of ethnic politics are clearly demarcated. Under this rationale, more Malays are including Islam in their discourses about, and protection of, Malay privileges. However, recent political turmoil and allegations of corruption within the Malay-dominant ruling party may also provide an impetus for Malays to turn to Islam for moral guidance. However, it can also be argued that Islamisation has less to do with religion and more with Malay ethnonationalism. Barr and Govindasamy (2010) suggest that what is seen as a process of Islamisation is actually a program of hegemony designed to condition nonMalays to accept their assimilation into the Malaysian nation as subordinate, peripheral partners. In any case, it seems that Islamisation is intimately tied to recurrent Malay discourses that position the Chinese and Indians as immigrant visitors, are not bona fide Malaysians who can hold equal citizenship as the international image might suggest, and may even be regarded as "disloyal 


\section{This is an Accepted Manuscript of an article published by Taylor \& Francis in Journal of Policy Research in Tourism, Leisure and Events on 3 July 2017, available online: http://www.tandfonline.com/doi/full/10.1080/19407963.2017.1344245}

foreigners" (Yow 2016:2). As pronounced during 2015 demonstrations amongst Chinese and Indian Malaysians about corruption in the current government, many Malays demanded that the Chinese and Indians respect the Malay language, Malay culture, the King, the Islamic Sultans, and ultimately to "know their place" (Channel News Asia 2015).

\section{Conclusion}

As the preceding discussion has sought to show, Malaysia's international image of harmonious multiculturalism - especially led by the very successive Malaysia, Truly Asia campaign to lure foreign tourists - is more a political brand (Pasotti 2010) than an accurate depiction of the country's domestic policies and experiences of cultural diversity. This paper brought the Malaysian tourism campaign face-to-face with current discourses, policy and existing scholarship on domestic experiences of cultural diversity in Malaysia. Far from having achieved interethnic egalitarianism as the tourism campaign may present, the Malaysian approach has been ethnocratic in favour of the Malays. Whereas that image articulates a multiculturalism that celebrates ethnic and cultural diversity, it hides a domestic policy that has pedetalised the Malay majority and has codified in constitutional law that Malay cultural, linguistic and religious values are superior. What is more, this international image has likely never been accurate because from the outset of independence, Malaysia has been officially defined in Malay cultural and linguistic terms, has privileged the Malay majority through affirmative action, and has sought to silence dissent from the ethnic Chinese and Indians. Malaysia does indeed host cultural pluralism, but the international image of successful and harmonious multiculturalism is an image sooner based on Western values of multiculturalism than Malaysia's staunchly Malay-centric policies. 


\section{This is an Accepted Manuscript of an article published by Taylor \& Francis in Journal of Policy Research in Tourism, Leisure and Events on 3 July 2017, available}

online: http://www.tandfonline.com/doi/full/10.1080/19407963.2017.1344245

What is more, it seems that an emerging new wave of Islamisation in domestic politics and society probably renders this image increasingly distant from, and unrepresentative of, the international image. Explanations for this new wave are probably many as this paper has broadly canvassed, including confidence amongst minorities in amplifying their demands for meritocracy. This has translated into discourses and events that can be seen as amounting to Malay-led Islamisation and further marginalising the nation's non-Malay ethnic groups. While the impact and future of this renewed Islamisation will continue to unfold in the coming years, it is in any case clear that the harmonious multicultural utopia woven into Malaysia's international branding is becoming increasingly less realistic. A question for the Malaysian government will be to what extent its international image of harmonious multiculturalism can continue to hold currency as an effective tourism campaign, and continue enjoy international purchase, if the image is increasingly rendered unrepresentative of Malaysian society.

\section{References}

Abbott, J. P., \& Gregorios-Pippas, S. (2010). Islamization in Malaysia: processes and dynamics. Contemporary Politics, 16(2), 135-151.

Adil, M. A. M. (2007). Law of Apostasy and Freedom of Religion in Malaysia. Asian Journal of Comparative Law, 2, 1-36.

Albury, N. J., \& Aye, K. K. (2016). Malaysia's national language policy in international theoretical context. Journal of Nusantara Studies, 1(1), 71-84.

Barr, M. D., \& Govindasamy, A. R. (2010). The Islamisation of Malaysia: Religious nationalism in the service of ethnonationalism. Australian Journal of International Affairs, 64(3), 293-311.

Benthall, J. (2005). Confessional cousins and the rest: The structure of Islamic toleration. Anthropology Today, 21(1), 16-20.

Boo, S.-L. (2015). Marina Mahathir: Malaysia undergoing ‘Arab colonialism'. Malay Mail Online. Retrieved from http://www.themalaymailonline.com/malaysia/article/marina-mahathirmalaysia-undergoing-arab-colonialism 


\section{This is an Accepted Manuscript of an article published by Taylor \& Francis in}

Journal of Policy Research in Tourism, Leisure and Events on 3 July 2017, available

online: http://www.tandfonline.com/doi/full/10.1080/19407963.2017.1344245

Bystrova, K. (2015, January 2015). Malaysia's Islamisation. Global - The International Briefing. Retrieved from http://www.global-briefing.org/2015/01/malaysias-islamisation/

Channel News Asia (Writer). (2015). Malaysian Politics.

Fenton, S. (2003). Malaysia and capitalist modernisation: Plural and multicultural models. International Journal on Multicultural Societies, 5(2), 135-147.

Fernando, J. M. (2006). The position of Islam in the constitution of Malaysia. Journal of Southeast Asian Studies, 37(02), 249-266.

FMT Reporters. (2016, April 21, 2016). Racial politics, not vernacular schools breeds racism. Free Malaysia Today. Retrieved from http://www.freemalaysiatoday.com/category/nation/2016/04/21/racial-politics-notvernacular-schools-breeds-racism/

Frith, T. (2000). Ethno-religious identity and urban Malays in Malaysia. Asian Ethnicity, 1(2), 117129.

G25 Malaysia. (2016, May 3, 2016). Stay true to police work. The Star Online. Retrieved from http://www.thestar.com.my/opinion/letters/2016/05/03/stay-true-to-police-work/

Ghazali, K. (2014). Language and Islam in Malaysian political speeches. International Journal of the Sociology of Language, 2014(229), 29-48.

Gill, S. K. (2005). Language policy in Malaysia: Reversing direction. Language Policy, 4(3), 241260.

Gill, S. K. (2013). Language Policy Challenges in Multi-Ethnic Malaysia. Dordrecht: Springer.

Guan, Y. S. (2011). In defence of the secular? Islamisation, Christians and (new) politics in urbane Malaysia. Asian Studies Review, 35(1), 83-103.

Hamayotsu, K. (2014). Towards a more democratic regime and society? The politics of faith and ethnicity in a transitional multi-ethnic Malaysia. Journal of Current Southeast Asian Affairs, 32(2), 61-88.

Haque, M. S. (2003). The Role of the State in Managing Ethnic Tensions in Malaysia A Critical Discourse. American Behavioral Scientist, 47(3), 240-266.

Hoffstaedter, G. (2013). Secular state, religious lives: Islam and the state in Malaysia. Asian Ethnicity, 14(4), 475-489.

Ibrahim, R. (2007). Multiculturalism and education in Malaysia. Culture and Religion, 8(2), 155167.

Joseph, J. (2003). Language and identity. London: Springer.

Kelly-Holmes, H. (2014). Linguistic fetish: The sociolinguistics of visual multilingualism. In D. Machin (Ed.), Visual Communication (Vol. 4, pp. 135-151). Berlin: De Gruyter Mouton.

Liow, J. C. Y. (2003). Deconstructing Islam in Malaysia: UMNO's response to PAS's religiopolitical dialectic. Singapore: IDSS, Institute of Defence and Strategic Studies, Singapore Working Papers 45.

Malay Mail Online. (2016a, February 12, 2016). Report: Malaysia's mission schools facing Islamisation with alleged conversions. Malay Mail Online. Retrieved from http://www.themalaymailonline.com/malaysia/article/report-malaysias-mission-schoolsfacing-islamisation-with-alleged-conversio 


\section{This is an Accepted Manuscript of an article published by Taylor \& Francis in}

Journal of Policy Research in Tourism, Leisure and Events on 3 July 2017, available

online: http://www.tandfonline.com/doi/full/10.1080/19407963.2017.1344245

Malay Mail Online. (2016b, March 24). Stop aping Arabs, Johor Sultan tells Malays. Malay Mail Online. Retrieved from http://www.themalaymailonline.com/malaysia/article/stop-apingarabs-johor-sultan-tells-malays

Malaysian Investment Development Authority. (2015). Why Malaysia. Retrieved April 30, 2016, from http://www.mida.gov.my/home/why-malaysia/posts/

Martinez, P. (2001). The Islamic state or the state of Islam in Malaysia. Contemporary Southeast Asia, 23(3), 474-503.

Martinez, P. (2004). Islam, constitutional democracy, and the Islamic state in Malaysia. Civil Society in Southeast Asia, 27-53.

May, S., \& Sleeter, C. E. (2010). Critical multiculturalism: Theory and praxis: Routledge.

Mohamad, M. (2010). he Ascendance of Bureaucratic Islam and the Secularization of the Sharia in Malaysia. Pacific Affairs, 83(3), 505-524.

Morais, D. (2013). Malaysia: Truly Asia. In G. Pultar (Ed.), Imagined Identities: Identity Formation in the Age of Globalization (pp. 92-110). Syracuse: Syracuse University Press.

Nanthakumar, L., Subramaniam, T., \& Kogid, M. (2012). Is' Malaysia Truly Asia'? Forecasting tourism demand from ASEAN using SARIMA approach. Tourismos, 7(1), 367-381.

Noor, N. M., \& Leong, C.-H. (2013). Multiculturalism in Malaysia and Singapore: Contesting models. International Journal of Intercultural Relations, 37(6), 714-726.

Parekh, B. C. (2002). Rethinking multiculturalism: Cultural diversity and political theory. Cambridge, MA: Harvard University Press.

Pasotti, E. (2010). Political branding in cities. Cambridge: Cambridge Universaity Press

Pennycook, A. (1994). The Cultural Politics of English as an International Language. London: Longman.

Property Investment. (2016). Real Estate Investment Malaysia - Why You Need to Start Investing Now Retrieved May 2, 2016, from http://propertyinvestment.com.my/real-estateinvestment-malaysia/

PwC. (2014). Doing Business in Malaysia 2014. from http://read.pwc.com/i/471175-doingbusiness-guide-for-malaysia-2014

Rahim, R. (2016, April 28, 2016). Sarawak polls: Malaysia known for upholding Islamic principles, says Najib. The Star Online. Retrieved from http://www.thestar.com.my/news/nation/2016/04/28/sarawak-polls-najib-islamic-principles/

Ridge, B. (2004). Bangsa Malaysia and recent Malaysian English language policies. Current Issues in Language Planning, 5(4), 407-423.

Saat, N. (2012). Islamising Malayness: Ulama discourse and authority in contemporary Malaysia. Contemporary Islam, 6(2), 135-153. doi: 10.1007/s11562-011-0172-9

Sloane-White, P. (2011). Working in the Islamic Economy: Sharia-ization and the Malaysian workplace. Sojourn: Journal of Social Issues in Southeast Asia, 26(2), 304-334.

Tourism Malaysia. (2014). 'Malaysia Truly Asia - The Essence of Asia Continues winning streak'. Retrieved April 30, 2016, from http://www.tourism.gov.my/media/view/malaysia-trulyasia-the-essence-of-asia-continues-winning-streak

Tourism Malaysia. (2015). Malaysia Truly Asia. Retrieved April 30, 2016, from http://www.tourism.gov.my/campaigns/view/malaysia-truly-asia 
This is an Accepted Manuscript of an article published by Taylor \& Francis in

Journal of Policy Research in Tourism, Leisure and Events on 3 July 2017, available

online: http://www.tandfonline.com/doi/full/10.1080/19407963.2017.1344245

UNICEF. (2016). Malaysia Country Report: Language Education and Social Cohesion (LESC) Initiative. Thailand: UNICEF East Asia and Pacific Regional Office Retrieved from http://www.unicef.org/eapro/Malaysia Country Report Report Language Education and Social_Cohesion_Initiative.pdf.

Yow, C. H. (2016). Ethnic Chinese in Malaysian citizenship: gridlocked in historical formation and political hierarchy. Asian Ethnicity, 1-19.

Zook, D. (2010). Making Space for Islam: Religion, Science, and Politics in Contemporary Malaysia. The Journal of Asian Studies, 69(4), 1143-1166. 